\section{Influence of slope on physical soil disturbance due to farm tractor forwarding in a Hyrcanian forest of northern Iran}

\author{
Meghdad Jourgholami ${ }^{(1)}$, Shoukuh Soltanpour ${ }^{(1)}$, Maryam \\ Etehadi Abari ${ }^{(1)}$, Eric K Zenner ${ }^{(2)}$
}

Tractor-based systems are the most common type of small-scale timber harvesting equipment in the Hyrcanian forest, where farm tractors equipped with a 2-wheel trailer typically perform forwarding operations for pulpwood and fuelwood. The objective of this study was to evaluate the effects of different frequencies of machine passes on soil bulk density (BD), penetration resistance (PR) and total porosity (TP) in different slope gradient and forwarding direction (i.e., uphill vs. downhill). The study, performed on a brown soil with a silt loam to loamy texture, was designed as a factorial experiment with three slope gradient/forwarding direction classes $(0-10 \%$ downhill forwarding slope, $10-$ $20 \%$ downhill forwarding slope and $0-10 \%$ uphill forwarding slope) and four traffic intensity classes: 0 (undisturbed control area), 1-4, 5-10 and >10 machine passes. Responses were assessed at four soil profile depth classes $(5,10$, 15 and $20 \mathrm{~cm})$. BD and PR significantly increased and TP significantly decreased with increasing machine traffic, with magnitudes of change that were not consistently greater in the upper $5 \mathrm{~cm}$ compared to the $20 \mathrm{~cm}$ soil profile depth class. Whereas the majority of changes in BD and TP occurred after fewer than 5 passes, large increases in PR occurred even after 10 passes. Changes of $B D, P R$ and TP in response to machine traffic differed significantly among slope gradient/forwarding direction classes. Increases in BD and PR and decreases in TP were largest on the $0-10 \%$ uphill forwarding slope, followed by the $10-20 \%$ downhill and $0-10 \%$ downhill forwarding slope. We conclude that the application of farm tractors in forwarding operations should be limited to gentle slopes and uphill forwarding with these machines should be avoided.

Keywords: Farm Tractor, Forwarding Operation, Soil Compaction, Penetration Resistance, Total Porosity

\section{Introduction}

The entry of forestry machineries into forest has resulted in some cases in levels of soil disturbance that may have adverse effects on forest ecosystems and subsequently on long-term tree growth (Miller \& Anderson 2002, Landsberg et al. 2003, Ilstedta et al. 2004, Murphy et al. 2004). Numerous studies have documented changes in physical soil properties following harvesting machine traffic, such as increased soil compac-

tion, soil displacement, rutting and soil profile disturbances (Adams \& Froehlich 1984, Wronski \& Murphy 1994, Rab 1996, Rohand et al. 2004, Eliasson 2005, Susnjar et al. 2006, Eliasson \& Wasterlund 2007, Horn et al. 2007, Wang et al. 2007, Zenner et al. 2007, Ampoorter et al. 2010, 2012, Picchio et al. 2012). For instance, soil compaction, in which soil pores (especially macropores) are destroyed and surface aggregates are broken down (Ampoorter et al. 2010), depend

(1) Department of Forestry and Forest Economics, Faculty of Natural Resources, University of Tehran, Zob-e-Ahan Street, 315854314 Karaj (Iran); (2) College of Agricultural Sciences, Pennstate University, 305 Forest Resources Building, University Park, 16802 PA (United States of America)

@ Meghdad Jourgholami (mjgholami@ut.ac.ir)

Received: Oct 06, 2013 - Accepted: Nov 25, 2013

Citation: Jourgholami M, Soltanpour S, Etehadi Abari M, Zenner EK, 2014. Influence of slope on physical soil disturbance due to farm tractor forwarding in a Hyrcanian forest of northern Iran. iForest 7: 342-348 [online 2014-04-17] URL: http://www.sisef.it/iforest/ contents/? id=ifor $1141-007$

Communicated by: Enrico Marchi on the soil texture and moisture at the time of harvest (McNabb et al. 2001, Bock \& Van Rees 2002), but also on the number of machines passing on a specific point. Generally, soil compaction occurs in the first ten passes of a vehicle, but most of the compaction occurs in the first three trips; subsequent passes generally have little additional effect (Gayoso \& Iroume 1991, Eliasson 2005, Eliasson $\&$ Wasterlund 2007, Ampoorter et al. 2010). So it would be appropriate to concentrate machine traffic on carefully designed skid trails in such a way to minimize the affected area and leave most trees undisturbed (Zenner \& Berger 2008, Ampoorter et al. 2010).

It is unclear, however, to what extent the slope gradient (i.e., longitudinal and transversal slope) of the skid trail and the direction of machine traffic (i.e., uphill vs. downhill) could modify the impacts of vehicle traffic on the soil. Whereas some studies have failed to document an effect of slope on bulk density following harvesting traffic (e.g., Sidle \& Drlica 1981, Jamshidi et al. 2008), others have shown that soil disturbances increase with slope gradient (Ezzati et al. 2012), possibly because machines slip more and remain in a given place for a longer time on steep terrain, causing soil pulling and dragging (Gayoso \& Iroume 1991). Thus, steepness may have an even stronger effect on soil disturbance than that of the soil moisture (Krag et al. 1986), but possibly less so than that of the traffic intensity (Ezzati et al. 2012).

Soil disturbance is also strongly affected by the type of harvesting equipment used. Small-scale harvesting technology, such as farm tractors or better small skidder or other specific machines (such as ATV), is thought to result in lower levels of residual stand and soil damage because the equipment is typically smaller and lighter than regular skidders (Updegraff \& Blinn 2000, Savelli et al. 2010, Spinelli \& Magagnotti 2012). A recent study dealing with soil compaction has found that the highest relative increase in bulk density was associated with the use of bulldozers, the lowest with the use of a forwarder, and intermediate levels with the use of a farm tractor and a rubber-tired cable skidder (Bustos \& Egan 2011). However, farm tractors have been designed primarily for use in an agricultural rather than a forest environment and must be modified for use as wheeled skidders, such as through the addition of a logging winch, a roll-over canopy, a blade, belly pan protection, valve stem protection, wheel chains and wheel weights (Conway 1984, Rodriguez 1986, Shaffer 1992, Dykstra \& Heinrich 1996, Greulich et al. 1999, Russell \& Mortimer 2005).

In the Hyrcanian forest of northern Iran, where rough topography and use of the sheltercut system favor small-scale harvesting 


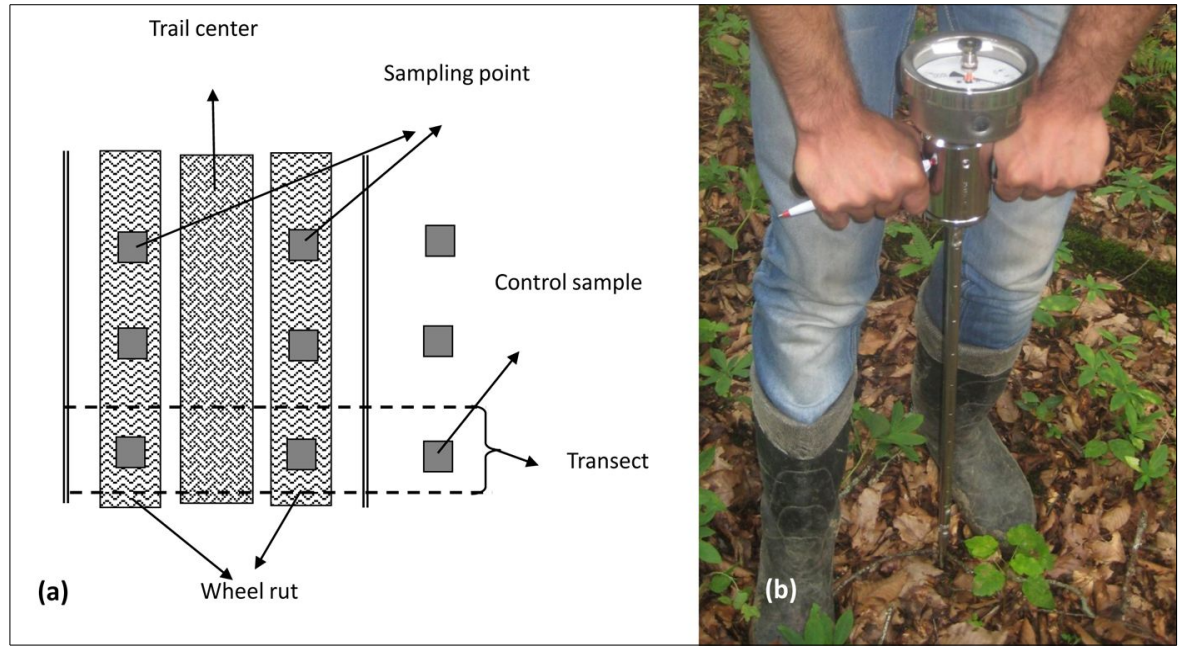

Fig. 1 - Experimental design of the field trail for the BD and PR sampling (a) and measurement of PR using a hand-held penetrometer (b).

operations, farm tractors often pull an additional two-wheeled trailer to forward the wood raised completely off the ground. The felling and on-site processing of felled trees with large diameters are typically done by chainsaw (Jourgholami 2012). Mechanization is largely limited to the transport function, whereby logs of 5-15 meter length are extracted with rubber-tired skidders to roadside landings and farm tractors and mules are the most common timber extraction systems for pulpwood and fuelwood. The advantages of using relatively light farm tractors with large-dimension tires in the rear axle is the large contact area of the tire with the soil and the reduced ground pressure. Although the addition of a trailer increases the payload per trip, thereby reducing the number of equipment passes with its associated soil disturbances, the trailer also reduces tractor maneuverability, potentially creating deep ruts in steep terrain and in uphill forwarding.

We hypothesized that the extent of the soil degradation from farm tractor forwarding operations along the upper $20 \mathrm{~cm}$ of the soil profile would increase with traffic frequency, but that these increases would vary with slope gradient and direction of forwarding (uphill or downhill). To test this hypothesis, we quantified soil bulk density, penetration resistance and total porosity in skid trails on different slope gradients with varying forwarding direction and traffic intensities.

\section{Materials and methods}

\section{Study sites}

The research was carried out in Compartments 311 and 319 of the Gorazbon district in the Kheyrud Forest in the Hyrcanian forest region of northern Iran. The studied forests range in elevation from 1050-1270 m a.s.l. with a prevailing southern aspect. Average rainfall ranges from 1150 to $1260 \mathrm{~mm}$ year $^{-1}$, with peaks in summer and autumn. Average daily temperatures range from a few degrees below $0{ }^{\circ} \mathrm{C}$ in December, January, and February to $+25^{\circ} \mathrm{C}$ during the summer. Soils are classified as well-drained forest brown soils (Alfisols) with a soil texture ranging from silt loam to loamy. The relief of the study area is characterized by carbonate rocks (limestone and dolomite) and their numerous karst forms: crests, carks in limestone, under-ground flows and sink hole structure. The study area is dominated by natural forests with native mixed deciduous tree species, including Fagus orientalis Lipsky, Carpinus betulus L., Alnus subcordata C.A.Mey, and Quercus castaneifolia C.A. Mey. The prevalent silvicultural treatment is a combination of the group selection and single tree selection methods, resulting in uneven-aged stands. Based on field data collected in October 2012, the average growing stock in compartments 311 and 319 was $289.1 \mathrm{~m}^{3} \mathrm{ha}^{-1}$ and $555.2 \mathrm{~m}^{3} \mathrm{ha}^{-1}$, respectively. A total of 240 trees $\left(9\right.$ trees ha $\left.{ }^{-1}\right)$ with a total volume of $940.2 \mathrm{~m}^{3}\left(33.8 \mathrm{~m}^{3} \mathrm{ha}^{-1}\right)$ were marked in compartment no. 311 and a total of 210 trees $\left(5\right.$ trees ha $\left.{ }^{-1}\right)$ with a total volume of $1177.3 \mathrm{~m}^{3}\left(27.5 \mathrm{~m}^{3} \mathrm{ha}^{-1}\right)$ were marked in compartment no. 319 .

\section{Experimental design and data collection}

A farm tractor equipped with a 2-wheel trailer (2-driving wheel) was used for forwarding pulp- and fuelwood. Technical specifications of the farm tractor were: UTB/ Universal 650 Engine UTB, diesel, 4-cylinder; Displacement: 4.8 1; Fuel capacity: 98.0 1; Mass: 3999 kg; Engine Power: 46.2 kW; Length: $414 \mathrm{~cm}$; Width: $199 \mathrm{~cm}$; Height: $260 \mathrm{~cm}$; 4WD; and trailer Mass: $1700 \mathrm{~kg}$. At the time of forwarding, weather conditions had been very dry and warm, and these conditions remained constant during the extrac- tion operation. The soil moisture was 20 $65 \%$ and the organic matter content was $11 \%$. The slope of the skid trail ranged from 0 to $20 \%$ and extraction distances to the landing area near the forest roadside were about $220 \mathrm{~m}$. A Suunto inclinometer was used for measuring slope in the skid trails. Calculation of slope was weighted as follows (Mousavi 2009 - eqn. 1):

$$
S=\frac{\sum_{i=1}^{n} d_{i} s_{i}}{\sum_{i=1}^{n} d_{i}}
$$

where $S$ is the average slope along the skid trail (percent), $d$ is the distance between two points in the sample (m), $s$ is the slope between two points in the sample (percent), $i$ is the sample number, and $n$ is the number of samples.

The average forwarded volume in each trip was $2280 \mathrm{~kg}$. Sampling transects were placed on different slope gradient classes along the designated skid trail (Fig. 1a). To ensure that traffic was restricted to the same tracks, painted sticks were implanted in the center of the skid trail as a guide for machinery operators. Before the forwarding operation with the farm tractor began, sampling plots were established in different skid trail segments on three slope gradients (i.e., $0-10 \%$ downhill, $10-20 \%$ downhill, and $0-10 \%$ uphill forwarding) that would be exposed to different levels of machine traffic, i.e., 0 (undisturbed), 1-4, 5-10 and >10 machine passes. A machine pass implies a drive both back and forth (i.e., with and without a wood load) on the selected trail segment. Each combination of slope by traffic frequency was replicated three times. Prior to and after the forwarding operations, soil response measurements (i.e., bulk density, resistance to penetration and total porosity) were obtained in each replicate at soil depths of 5 , 10,15 and $20 \mathrm{~cm}$ in the wheel rut as well as in control sample points adjacent to the skid trail (Fig. 1a). Organic horizons were removed from the soil surface prior to bulk density and penetration resistance measurements, so that measurements were referenced to the mineral soil surface. Soil sample cores were taken from the top mineral soil using a thin walled steel cylinder, $40 \mathrm{~mm}$ long and $56 \mathrm{~mm}$ in diameter, driven into the soil by a hammer-driven device. After extracting the steel cylinder, soil cores were trimmed flush with the cylinder end and extruded into a plastic bag for transport to the laboratory. Samples were weighed on the day they were collected and again after oven-drying at 105 ${ }^{\circ} \mathrm{C}$ for $24 \mathrm{~h}$ to determine water content and bulk density. Soil penetration resistance $(P R)$ was measured using a hand-held soil penetrometer (Fig. 1b). The study yielded $144 P R$ readings (samples) before and after 
treatment. When the penetrometer had hit a buried rock or tree roots, the readings were ignored.

Soil porosity $(T P)$ was determined by the following equation (eqn. 2):

$$
T P=\frac{(P D-B D)}{P D} \cdot 100
$$

where $P D$ is the particle density measured by a pycnometer on the same soil samples used to determine the bulk density $(B D)$. A pycnometer is a device used to determine the density of a liquid. Such instrument is usually made of glass, with a close-fitting ground glass stopper with a capillary tube through it, so that air bubbles may escape from the apparatus. This device enables a liquid's density to be measured accurately by reference to an appropriate working fluid, such as water or mercury, using an analytical balance. Particle density (PD) was calculated as follows (eqn. 3):

$$
P D=\frac{d w \cdot W s}{W s-(W s w-W w)}
$$

where $d w$ is the density of water $\left(\mathrm{g} \mathrm{cm}^{-3}\right)$ at the temperature observed, $W s$ is the weight of soil sample (oven dry), $W s w$ is the weight of pycnometer, soil and water, and $W w$ is the weight of pycnometer and water.

\section{Statistical analysis}

The experimental design was a factorial arrangement of treatments conducted in a completely randomized design. We applied general linear modeling (GLM) to relate bulk density, penetration resistance and total porosity to the slope gradient (three classes), machine passes (four classes), soil depth (four classes) and their interactions. Since no departure from normal distribution of the data was observed after Kolmogorov-Smirnov test $(\alpha=0.05)$, standard parametric analyses were carried out. Homogeneity of variance among treatments was verified by the Levene's test $(\alpha=0.01)$. Post-hoc comparison of group means was performed using the Duncan's multiple range test with a $99 \%$ confidence level. Treatment effects were considered significant when $\mathrm{P}<0.01$.

All statistical analyses were carried using the SPSS (release 15.0) statistical package.

\section{Results}

\section{Bulk density}

Slope gradient (SG), traffic intensity $(\mathrm{T})$ and soil profile depth (D - depth readings were referenced to the mineral soil surface), as well as the interaction effects of $\mathrm{SG} \times \mathrm{T}$, $\mathrm{SG} \times \mathrm{D}, \mathrm{SG} \times \mathrm{D}$ and $\mathrm{SG} \times \mathrm{T} \times \mathrm{D}$ significantly affected $B D$ (Tab. 1 and Tab. 2). Average $B D$ varied significantly among slope gradients and ranged from $1.20 \mathrm{~g} \mathrm{~cm}^{-3}$ on the $0-10 \%$ downhill forwarding slope, $1.35 \mathrm{~g} \mathrm{~cm}^{-3}$ on

Tab. 1 - Means \pm standard deviation of different physical soil properties on skid trails after forwarding with a farm tractor. $(B D)$ : bulk density; $(T P)$ : total porosity; $(P R)$ : penetration resistance. Different letters indicate statistically significant differences within columns for each

\begin{tabular}{|c|c|c|c|c|c|}
\hline $\begin{array}{c}\text { Slope } \\
(\%)\end{array}$ & $\begin{array}{c}\text { Traffic } \\
\text { (\# of passes) }\end{array}$ & $\begin{array}{c}\text { Depth } \\
\text { (cm) }\end{array}$ & $\begin{array}{c}B D \\
\left(\mathrm{~g} \mathrm{~cm}^{-3}\right)\end{array}$ & $\begin{array}{c}P R \\
(\mathrm{kPa})\end{array}$ & $\begin{array}{c}T P \\
(\%)\end{array}$ \\
\hline $0-10 \%$ & 0 & $0-5$ & $1.02 \pm 0.01^{\mathrm{d}}$ & $1367.7 \pm 35.7^{\mathrm{b}}$ & $55.3 \pm 1.1^{\mathrm{a}}$ \\
\hline \multirow[t]{15}{*}{ (down) } & & $5-10$ & $1.09 \pm 0.02^{\mathrm{c}}$ & $1366.0 \pm 24.2^{b}$ & $53.6 \pm 4^{\mathrm{a}}$ \\
\hline & & $10-15$ & $1.18 \pm 0.01^{\mathrm{b}}$ & $1382.7 \pm 16.2^{\mathrm{ab}}$ & $51.1 \pm 2.7^{\mathrm{a}}$ \\
\hline & & $15-20$ & $1.23 \pm 0.01^{\mathrm{a}}$ & $1429.3 \pm 19^{\mathrm{a}}$ & $45.3 \pm 1.7^{\mathrm{b}}$ \\
\hline & $<5$ & $0-5$ & $1.09 \pm 0.01^{\mathrm{d}}$ & $1487.3 \pm 2.9^{\mathrm{a}}$ & $53.5 \pm 2.5^{\mathrm{a}}$ \\
\hline & & $5-10$ & $1.17 \pm 0.01^{\mathrm{c}}$ & $1470.3 \pm 44.7^{\mathrm{a}}$ & $49.4 \pm 1.6^{\mathrm{at}}$ \\
\hline & & $10-15$ & $1.21 \pm 0.02^{\mathrm{b}}$ & $1496.7 \pm 86.6^{\mathrm{a}}$ & $43.7 \pm 6.5^{b}$ \\
\hline & & $15-20$ & $1.28 \pm 0.01^{\mathrm{a}}$ & $1562.3 \pm 48.1^{\mathrm{a}}$ & $44.8 \pm 3.3^{b}$ \\
\hline & $5-10$ & $0-5$ & $1.07 \pm 0.01^{\mathrm{d}}$ & $1614.0 \pm 45.6^{\mathrm{a}}$ & $55.0 \pm 1.6^{\mathrm{a}}$ \\
\hline & & $5-10$ & $1.21 \pm 0.02^{\mathrm{c}}$ & $1553.7 \pm 18.3^{\mathrm{ab}}$ & $45.6 \pm 0.7^{b}$ \\
\hline & & $10-15$ & $1.25 \pm 0.01^{\mathrm{b}}$ & $1541.3 \pm 43^{\mathrm{b}}$ & $44.4 \pm 1.7^{\mathrm{b}}$ \\
\hline & & $15-20$ & $1.33 \pm 0.01^{\mathrm{a}}$ & $1498.0 \pm 18.2^{b}$ & $40.0 \pm 2.9^{c}$ \\
\hline & $>10$ & $0-5$ & $1.15 \pm 0.02^{\mathrm{c}}$ & $1595.7 \pm 27.4^{b}$ & $48.8 \pm 1.7^{\mathrm{a}}$ \\
\hline & & $5-10$ & $1.25 \pm 0.01^{\mathrm{b}}$ & $1643.3 \pm 20.8^{\mathrm{ab}}$ & $47.1 \pm 1.9^{\mathrm{a}}$ \\
\hline & & $10-15$ & $1.34 \pm 0.03^{\mathrm{a}}$ & $1690.0 \pm 45.8^{\mathrm{a}}$ & $43.3 \pm 2.2^{\mathrm{a}}$ \\
\hline & & $15-20$ & $1.37 \pm 0.04^{\mathrm{a}}$ & $1695.3 \pm 32.3^{\mathrm{a}}$ & $44.3 \pm 6.4^{\mathrm{a}}$ \\
\hline \multirow{16}{*}{$\begin{array}{c}10-20 \% \\
\text { (down) }\end{array}$} & 0 & $0-5$ & $1.03 \pm 0.01^{\mathrm{d}}$ & $1343.3 \pm 32.1^{\mathrm{c}}$ & $56.2 \pm 2.4^{\mathrm{a}}$ \\
\hline & & $5-10$ & $1.09 \pm 0.01^{\mathrm{c}}$ & $1366.7 \pm 30.6^{c}$ & $53.8 \pm 3.7^{\mathrm{at}}$ \\
\hline & & $10-15$ & $1.19 \pm 0.01^{\mathrm{b}}$ & $1433.3 \pm 28.9^{b}$ & $50.7 \pm 2.3^{\mathrm{bc}}$ \\
\hline & & $15-20$ & $1.24 \pm 0.01^{\mathrm{a}}$ & $1486.7 \pm 5.8^{\mathrm{a}}$ & $47.2 \pm 2.4^{\mathrm{c}}$ \\
\hline & $<5$ & $0-5$ & $1.23 \pm 0.02^{\mathrm{d}}$ & $1672.0 \pm 41.1^{\mathrm{b}}$ & $47.6 \pm 2.4^{\mathrm{a}}$ \\
\hline & & $5-10$ & $1.37 \pm 0.01^{\mathrm{c}}$ & $1676.7 \pm 11.6^{\mathrm{b}}$ & $41.2 \pm 1.7^{\mathrm{b}}$ \\
\hline & & $10-15$ & $1.43 \pm 0.02^{\mathrm{b}}$ & $1717.7 \pm 42.4^{\mathrm{ab}}$ & $37.5 \pm 1.8^{\mathrm{b}}$ \\
\hline & & $15-20$ & $1.47 \pm 0.03^{\mathrm{a}}$ & $1778.7 \pm 51.4^{\mathrm{a}}$ & $38.2 \pm 4.6^{\mathrm{b}}$ \\
\hline & $5-10$ & $0-5$ & $1.29 \pm 0.02^{\mathrm{d}}$ & $1763.3 \pm 36.1^{\mathrm{a}}$ & $45.8 \pm 6.4^{\mathrm{a}}$ \\
\hline & & $5-10$ & $1.41 \pm 0.02^{\mathrm{c}}$ & $1776.7 \pm 38.3^{\mathrm{a}}$ & $43.3 \pm 1.1^{\mathrm{a}}$ \\
\hline & & $10-15$ & $1.45 \pm 0.01^{\mathrm{b}}$ & $1752.0 \pm 18.4^{\mathrm{a}}$ & $40.4 \pm 1.3^{\mathrm{at}}$ \\
\hline & & $15-20$ & $1.52 \pm 0.01^{\mathrm{a}}$ & $1807.7 \pm 51.9^{\mathrm{a}}$ & $33.6 \pm 3.9^{b}$ \\
\hline & $>10$ & $0-5$ & $1.36 \pm 0.03^{\mathrm{c}}$ & $1895.3 \pm 49.5^{\mathrm{a}}$ & $41.2 \pm 3.0^{\mathrm{a}}$ \\
\hline & & $5-10$ & $1.45 \pm 0.01^{\mathrm{b}}$ & $1943.7 \pm 37.6^{\mathrm{a}}$ & $39.1 \pm 5.4^{\mathrm{a}}$ \\
\hline & & $10-15$ & $1.51 \pm 0.02^{\mathrm{a}}$ & $1916.7 \pm 30.6^{\mathrm{a}}$ & $34.0 \pm 7.8^{\mathrm{a}}$ \\
\hline & & $15-20$ & $1.52 \pm 0.01^{\mathrm{a}}$ & $1953.3 \pm 15.3^{\mathrm{a}}$ & $35.5 \pm 3.0^{\mathrm{a}}$ \\
\hline \multirow{16}{*}{$\begin{array}{l}0-10 \% \\
\text { (up) }\end{array}$} & 0 & $0-5$ & $1.04 \pm 0.02^{\mathrm{d}}$ & $1376.7 \pm 20.8^{b}$ & $57.8 \pm 0.9^{\mathrm{a}}$ \\
\hline & & $5-10$ & $1.10 \pm 0.01^{\mathrm{c}}$ & $1356.7 \pm 32.1^{\mathrm{ab}}$ & $50.8 \pm 1.0^{\mathrm{b}}$ \\
\hline & & $10-15$ & $1.17 \pm 0.02^{\mathrm{b}}$ & $1380.0 \pm 17.3^{\mathrm{ab}}$ & $48.7 \pm 1.6^{\mathrm{bc}}$ \\
\hline & & $15-20$ & $1.24 \pm 0.01^{\mathrm{a}}$ & $1423.3 \pm 25.2^{\mathrm{a}}$ & $47.1 \pm 3.0^{\mathrm{c}}$ \\
\hline & $<5$ & $0-5$ & $1.41 \pm 0.02^{\mathrm{a}}$ & $1577.0 \pm 28.6^{c}$ & $38.1 \pm 5.5^{\mathrm{a}}$ \\
\hline & & $5-10$ & $1.50 \pm 0.02^{\mathrm{b}}$ & $1674.0 \pm 50.5^{b}$ & $30.8 \pm 4.4^{\mathrm{at}}$ \\
\hline & & $10-15$ & $1.57 \pm 0.01^{\mathrm{a}}$ & $1727.3 \pm 34.1^{b}$ & $35.8 \pm 2.5^{\mathrm{at}}$ \\
\hline & & $15-20$ & $1.58 \pm 0.02^{\mathrm{a}}$ & $1826.7 \pm 23.1^{\mathrm{a}}$ & $29.9 \pm 2.7^{b}$ \\
\hline & $5-10$ & $0-5$ & $1.49 \pm 0.02^{\mathrm{c}}$ & $1953.3 \pm 15.3^{c}$ & $34.0 \pm 1.2^{\mathrm{a}}$ \\
\hline & & $5-10$ & $1.58 \pm 0.01^{\mathrm{b}}$ & $2067.3 \pm 50.0^{\mathrm{b}}$ & $30.1 \pm 2.2^{\mathrm{a}}$ \\
\hline & & $10-15$ & $1.61 \pm 0.03^{\mathrm{ab}}$ & $2078.3 \pm 44.1^{\mathrm{b}}$ & $26.6 \pm 2.7^{\mathrm{at}}$ \\
\hline & & $15-20$ & $1.64 \pm 0.02^{\mathrm{a}}$ & $2166.7 \pm 54.6^{\mathrm{a}}$ & $30.7 \pm 1.8^{b}$ \\
\hline & $>10$ & $0-5$ & $1.55 \pm 0.02^{\mathrm{b}}$ & $2197.7 \pm 81.0^{\mathrm{a}}$ & $34.1 \pm 1.8^{\mathrm{a}}$ \\
\hline & & $5-10$ & $1.63 \pm 0.02^{\mathrm{a}}$ & $2152.7 \pm 10.5^{\mathrm{a}}$ & $34.8 \pm 4.7^{\mathrm{a}}$ \\
\hline & & $10-15$ & $1.63 \pm 0.02^{\mathrm{a}}$ & $2196.7 \pm 70.1^{\mathrm{a}}$ & $30.8 \pm 3.9^{\mathrm{a}}$ \\
\hline & & $15-20$ & $1.65 \pm 0.02^{\mathrm{a}}$ & $2193.0 \pm 37.4^{\mathrm{a}}$ & $30.2 \pm 4.5^{\mathrm{a}}$ \\
\hline
\end{tabular}
slope class separately $(\mathrm{P}<0.01)$, based on analysis of variance (GLM).

the $10-20 \%$ downhill forwarding slope and $1.46 \mathrm{~g} \mathrm{~cm}^{-3}$ on the $0-10 \%$ uphill forwarding slope. Average $B D$ increased significantly with increasing frequency of machine passes and reached the highest level of $1.45 \mathrm{~g} \mathrm{~cm}^{-3}$ after 10 passes. Average $B D$ also increased significantly with increasing soil profile depth. However, the major increases following forwarding occurred at the soil surface
$(0-5 \mathrm{~cm})$, particularly on the $0-10 \%$ uphill forwarding slope and the $10-20 \%$ downhill forwarding slope.

The effects of significant interactions of slope gradient with traffic intensity and soil profile depth on $B D$ are shown in Fig. 2. Average $B D$ increased with increasing traffic intensity, regardless of slope gradient, but throughout the profile $B D$ increase was par- 
Tab. 2 - Analysis of variance (ANOVA) for the effects of slope gradient (SG), traffic inten sity (T), soil profile depth (D) classes and their interactions on $B D$ after forwarding with a farm tractor.

\begin{tabular}{lccccc}
\hline Source & $\begin{array}{c}\text { Sum of } \\
\text { Squares }\end{array}$ & df & $\begin{array}{c}\text { Mean } \\
\text { Square }\end{array}$ & $\boldsymbol{F}$-value & $\boldsymbol{P}$-value \\
\hline $\mathrm{SG}$ & 1.61 & 2 & 0.81 & 3224.34 & $<0.001$ \\
$\mathrm{~T}$ & 2.11 & 3 & 0.7 & 2811.7 & $<0.001$ \\
$\mathrm{D}$ & 0.79 & 3 & 0.26 & 1049.24 & $<0.001$ \\
$\mathrm{SG} \times \mathrm{T}$ & 0.51 & 6 & 0.08 & 339.78 & $<0.001$ \\
$\mathrm{SG} \times \mathrm{D}$ & 0.02 & 6 & 0 & 12.31 & $<0.001$ \\
$\mathrm{~T} \times \mathrm{D}$ & 0.02 & 9 & 0 & 8.2 & $<0.001$ \\
$\mathrm{SG} \times \mathrm{T} \times \mathrm{D}$ & 0.02 & 18 & 0 & 3.92 & $<0.001$ \\
\hline
\end{tabular}

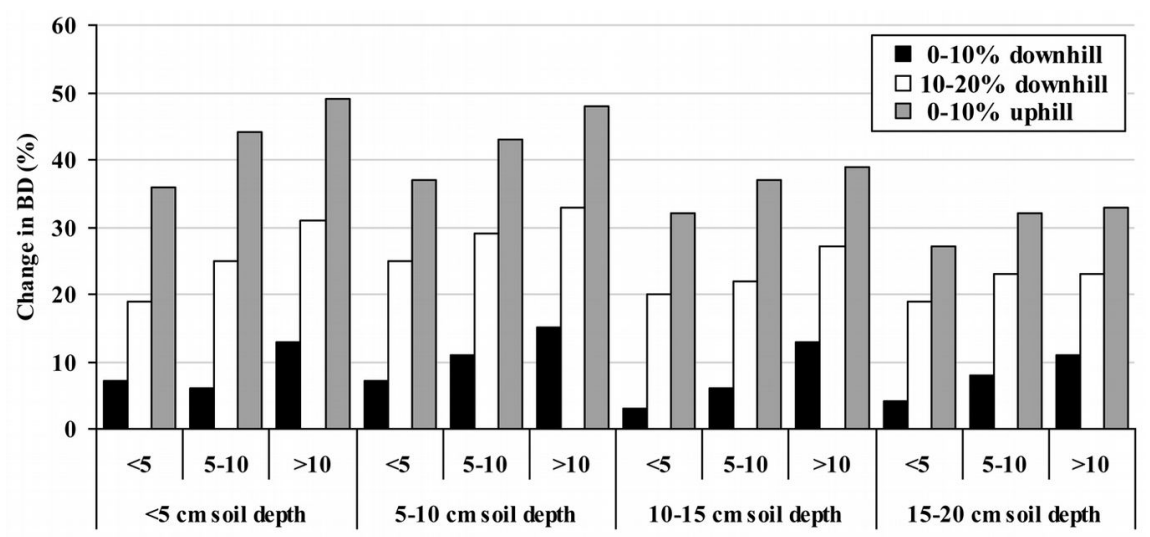

Fig. 2 - Change in $B D(\%)$ after forwarding by slope gradient class, traffic intensity class and soil profile depth class. Changes are relative to measurements from the same profile depth class in untrafficked control plots.

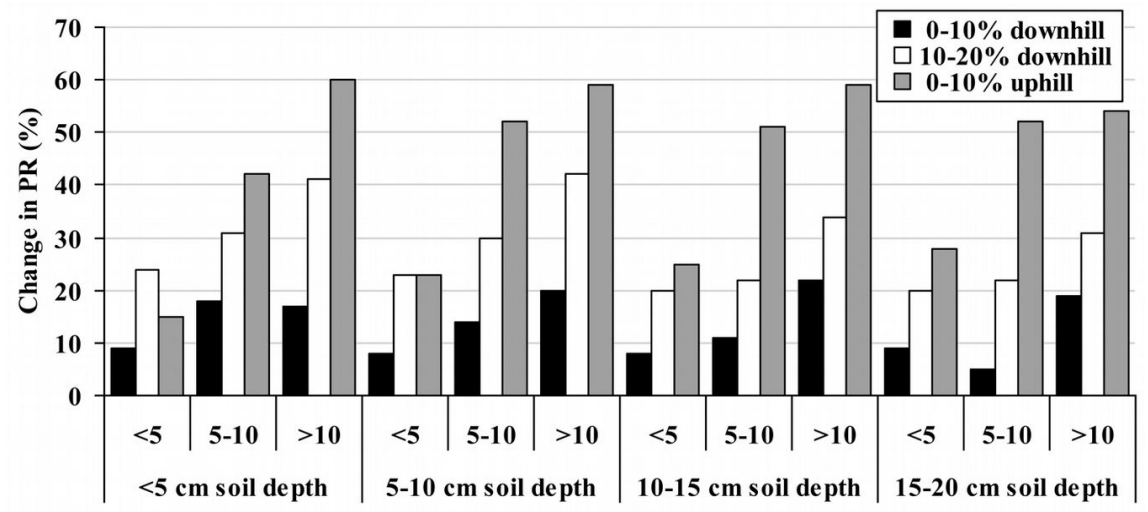

Fig. 3 - Change in $P R(\%)$ after forwarding by slope gradient class, traffic intensity class and soil profile depth class. Changes are relative to measurements from the same profile depth class in untrafficked control plots.

Tab. 3 - Analysis of variance (ANOVA) for the effects of slope gradient (SG), traffic intensity (T), soil profile depth (D) classes and their interactions on $P R$ after forwarding with a farm tractor.

\begin{tabular}{lcccrc}
\hline Source & $\begin{array}{c}\text { Sum of } \\
\text { Squares }\end{array}$ & df & $\begin{array}{c}\text { Mean } \\
\text { Square }\end{array}$ & $\boldsymbol{F}$-value & $\boldsymbol{P}$-value \\
\hline $\mathrm{SG}$ & 2321852 & 2 & 1160926 & 860.29 & $<0.001$ \\
$\mathrm{~T}$ & 5643747 & 3 & 1881249 & 1394.08 & $<0.001$ \\
$\mathrm{D}$ & 134033.1 & 3 & 44677.71 & 33.11 & $<0.001$ \\
$\mathrm{SG} \times \mathrm{T}$ & 1286932 & 6 & 214488.7 & 158.95 & $<0.001$ \\
$\mathrm{SG} \times \mathrm{D}$ & 29403.57 & 6 & 4900.59 & 3.63 & $<0.001$ \\
$\mathrm{~T} \times \mathrm{D}$ & 38066.81 & 9 & 4229.65 & 3.13 & $<0.001$ \\
$\mathrm{SG} \times \mathrm{T} \times \mathrm{D}$ & 110708.2 & 18 & 6150.45 & 4.56 & $<0.001$ \\
\hline
\end{tabular}

ticularly strong in plots with fewer than 5 passes on the $0-10 \%$ uphill and $10-20 \%$ downhill forwarding slope compared with control plots. The highest average $B D$ values were observed on the $0-10 \%$ uphill forwarding slope with $>10$ machine passes (Tab. 1), which also experienced the greatest amount of relative change (Fig. 3). Further, average $B D$ increased with increasing soil profile depth in each slope gradient class (Tab. 1), but relative changes were greatest in the upper $10 \mathrm{~cm}$ than of the soil profile (Fig. 2). The highest average $B D$ values were observed on the $0-10 \%$ uphill forwarding slope at a soil depth of 15-20 cm (Tab. 1).

\section{Penetration resistance}

Slope gradient (SG), traffic intensity $(\mathrm{T})$ and soil profile depth (D), as well as the interaction effects of $\mathrm{SG} \times \mathrm{T}, \mathrm{SG} \times \mathrm{D}, \mathrm{SG} \times \mathrm{D}$ and $\mathrm{SG} \times \mathrm{T} \times \mathrm{D}$ significantly affected $P R$ (Tab. 3 ). Average $P R$ by slope gradient was $1525 \mathrm{kPa}$ on the $0-10 \%$ downhill, $1705 \mathrm{kPa}$ on the 10 $20 \%$ downhill and $1834 \mathrm{kPa}$ on the $0-10 \%$ uphill forwarding slope. Average $P R$ increased significantly with increasing the frequency of machine passes and reached the highest level of $1922 \mathrm{kPa}$ after 10 passes. Average $P R$ also increased significantly with increasing soil profile depth.

Average $P R$ increased significantly with increasing traffic intensity, regardless of slope gradient, with particularly strong $P R$ increases on the $10-20 \%$ downhill and the 0 $10 \%$ uphill forwarding slope compared to control plots; the increase in $P R$ on the trafficked $0-10 \%$ downhill forwarding slope was lower at all traffic intensities and soil depths (Fig. 3). Compared to undisturbed control areas, which had $P R$ values of $1386 \mathrm{kPa}$ on the $0-10 \%$ downhill, $1408 \mathrm{kPa}$ on the 10 $20 \%$ downhill and $1384 \mathrm{kPa}$ on the $0-10 \%$ uphill forwarding slope, average $P R$ values after $>10$ machine passes increased to 1656 $\mathrm{kPa}$ on the $0-10 \%$ downhill, $1927 \mathrm{kPa}$ on the $10-20 \%$ downhill and $2185 \mathrm{kPa}$ on the 0 $10 \%$ uphill forwarding slope. Soil penetration resistance continually increased with traffic frequency in each soil depth and was still increasing at $>10$ passes, particularly on the $0-10 \%$ uphill and $10-20 \%$ downhill forwarding slope (Fig. 3). Although the highest average $P R$ values were found on the $0-10 \%$ uphill forwarding slope at a soil depth of 10$20 \mathrm{~cm}, P R$ did not increase significantly with soil depth in any of the slope gradients.

\section{Total porosity}

Slope gradient (SG), traffic intensity (T) and soil profile depth (D) as well as the interaction of $\mathrm{SG} \times \mathrm{T}$ significantly affected $T P$ (Tab. 4). Average TP by slope gradient was $47.8 \%$ on the $0-10 \%$ downhill, $42.8 \%$ on the $10-20 \%$ downhill and $36.9 \%$ on the $0-10 \%$ uphill forwarding slope (Fig. 4). Average $T P$ decreased significantly with increasing the 
traffic intensity and reached the lowest level of $38.6 \%$ after 10 passes. However, differences in $T P$ were small among trafficked plots. TP also decreased significantly with increasing soil profile depth (Tab. 1).

Average $T P$ was highest in control plots and decreased with increasing traffic intensity, regardless of slope gradient (Tab. 1). Particularly strong $T P$ decreases were observed in plots with fewer than 5 passes on the $0-10 \%$ uphill and $10-20 \%$ downhill forwarding slope as compared to control plots. Generally, only small additional decreases in $T P$ were observed with additional passes (Fig. 4). The lowest average $T P$ values were observed on the $0-10 \%$ uphill forwarding slope after the first 5 passes $(29.9 \%)$, where $T P$ was $17.5 \%$ lower compared to the controls (Tab. 1).

\section{Discussion}

In this study, the investigated physical soil properties exhibited consistent and largely predictable responses to different tractor traffic intensities throughout the upper 20 $\mathrm{cm}$ of the soil profile. The significant impact of traffic intensity on $B D, P R$ and $T P$ on all slope gradients is consistent with findings from previous studies that have documented a marked increase of bulk density, soil strength and loss of macropores with increasing traffic intensity (Sidle \& Drlica 1981, Gayoso \& Iroume 1991, Eliasson 2005, Susnjar et al. 2006, Ampoorter et al. 2010, Picchio et al. 2012). The large initial increase in compaction with fewer than 5 machine passes and the modest increase thereafter reflects the typical logarithmic relationship between the degree of soil compaction and the traffic intensity, where the greatest impacts occur during the first three passes and traffic intensities beyond 10 passes contribute very little to further compaction (Greacen \& Sands 1980, Gayoso \& Iroume 1991, Eliasson 2005, Eliasson \& Wasterlund 2007, Horn et al. 2007, Jamshidi et al. 2008, Bolding et al. 2009, Ampoorter et al. 2010, Picchio et al. 2012). One explanation for this logarithmic relationship is that the bearing capacity of the soil (maximum load without soil structure failure) grows with increasing $B D$, protecting the surface layer against further compaction with increasing traffic (Bolding et al. 2009, Ampoorter et al. 2010, Picchio et al. 2012). The increase in $P R$ beyond 10 passes observed in this study is in agreement with findings that $P R$ does not taper off after a few passes but continues to increase with traffic frequencies well beyond the traffic intensity seen in this study (Zenner et al. 2007). $P R$ is a more sensitive measure of logging traffic intensity than bulk density, because particle rearrangement after soil disturbance can increase $P R$ but not bulk density (Froehlich \& McNabb 1984) and greater increases in $P R$ than bulk density are com-

Tab. 4 - Analysis of variance (ANOVA) for the effects of slope gradient (SG), traffic intensity (T), soil profile depth (D) classes and their interactions on TP after forwarding with a farm tractor.

\begin{tabular}{lccccc}
\hline Source & $\begin{array}{c}\text { Sum of } \\
\text { Squares }\end{array}$ & df & $\begin{array}{c}\text { Mean } \\
\text { Square }\end{array}$ & $\boldsymbol{F}$-value & $\boldsymbol{P}$-value \\
\hline SG & 2873.63 & 2 & 1436.81 & 126.25 & $<0.001$ \\
T & 3955.4 & 3 & 1318.47 & 115.85 & $<0.001$ \\
D & 1443.86 & 3 & 481.29 & 42.29 & $<0.001$ \\
SG $\times$ T & 1013.74 & 6 & 168.96 & 14.85 & $<0.001$ \\
SG $\times$ D & 61.63 & 6 & 10.27 & 0.9 & 0.50 \\
T $\times$ D & 128.83 & 9 & 14.31 & 1.26 & 0.27 \\
SG $\times$ T $\times$ D & 281.26 & 18 & 15.63 & 1.37 & 0.16 \\
\hline
\end{tabular}

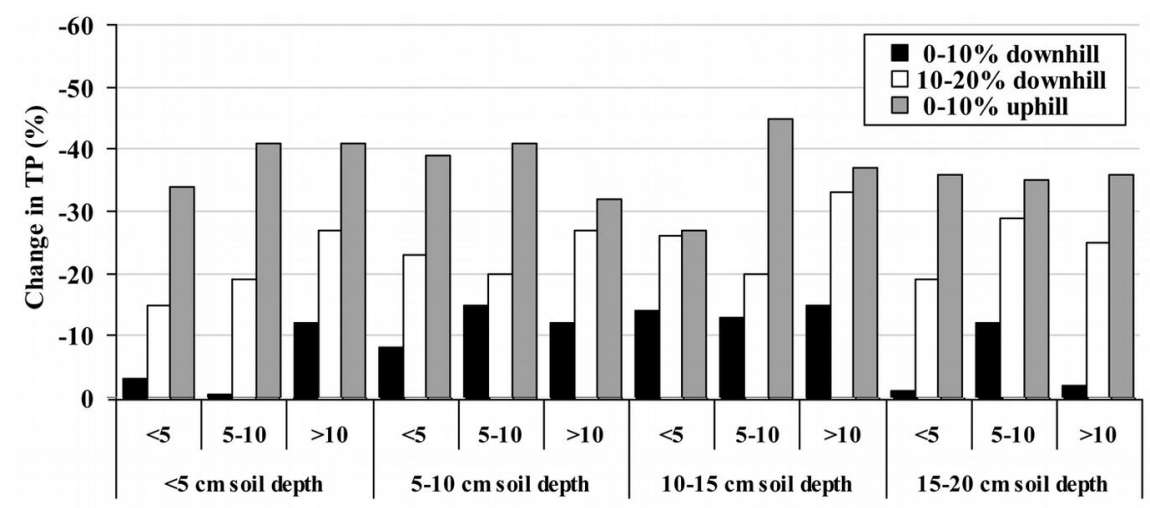

Fig. 4 - Change in $T P(\%)$ after forwarding by slope gradient class, traffic intensity class and soil profile depth class. Changes are relative to measurements from the same profile depth class in untrafficked control plots.

monly found for the same logging intensity (Alban et al. 1994, Brais 2001). The maximum $P R$ increase of up to $60 \%$ observed in this study is similar to the $50 \%$ increase reported by Picchio et al. (2012), but maximum $P R$ values of $2.3 \mathrm{MPa}$ did not reach levels where root growth of trees becomes restricted (e.g., 2.5-3 MPa; Greacen \& Sands 1980, Bolding et al. 2009).

The reduction in TP of up to $45 \%$ in this study is similar to that reported by previous analyses, and is likely due to a loss or substantial decrease $(50-60 \%)$ of macropores in favor of smaller pores after the first few machine passes (Ampoorter et al. 2010, Picchio et al. 2012). In the soil compaction process, soil pores are typically compressed or destroyed, surface aggregates are broken down, and macropores are transformed into meso$(0.2<\mathrm{d}<50 \mu \mathrm{m})$ and micropores $(\mathrm{d}<0.2 \mu \mathrm{m})$. As substantial destruction of macropores can already occur after the first few passes, this would explain why additional machine traffic only minimally decreased $T P$ beyond the initial reduction.

Even though the tendency of increased $B D$ and $P R$ and decreased $T P$ with increased traffic intensity was observed in all slope classes, the observed changes were highest when the forwarding direction was uphill (even on moderate slopes and after just a few passes) or on steeper slopes when the for- warding direction was downhill. Differences in levels of compaction between uphill and downhill forwarding may be explained by an uneven load distribution between the downhill and uphill tires of the skidder (Jamshidi et al. 2008) or increased wheel slippage and vibration in uphill compared to downhill forwarding. Because stresses applied at the soil surface are always transmitted three-dimensionally, they cause not only soil compaction but also shear effects (Horn et al. 2007) and exposure of mineral subsoil, which naturally has a higher $B D$ and $P R$ than the surface layer. Further, slope gradient has been found to be an important factor for the potential level of compaction (Sidle \& Drlica 1981), presumably because machines can slip continuously and remain longer in a given spot in steeper terrain, thus puddling and dragging the soil (Gayoso \& Iroume 1991).

An increase in $B D$ and $P R$ and a decrease in $T P$ with soil depth, as observed in control plots on all slope classes in this study, is typical for soil profiles. In untrafficked forest soils, $B D$ and $P R$ are typically low and $T P$ is high in the surface horizons due to large amounts of organic matter; as the organic matter content decreases with soil depth, $B D$ and $P R$ increase and $T P$ decreases (Gent \& Morris 1986, Eliasson \& Wasterlund 2007). Further, biological activity of roots and animals can reduce $B D$ and $P R$ and increase $T P$ 
in the upper soil, while fine soil texture, gravel content and soil structure may increase $B D$ and $P R$ and lower $T P$ at lower soil depths (Greacen \& Sands 1980, Ampoorter et al. 2010, Picchio et al. 2012). The pore volume of a medium- to fine-textured soil consists mainly of meso- and micropores that easily hold water against gravitational forces. The smaller the pore diameter, the more the adhesion of water molecules to soil colloids exceeds the force of gravitational capillarity. So in a saturated state, all pores are filled with water that cannot be compressed. Soil moisture content determines the proportion between soil compaction and plastic deformation (in the form of rutting) after the application of machine forces (Ampoorter et al. 2012). Tractor traffic with its associated wheel or track slip can directly affect the soil structure and alter physical soil properties down to deeper depths. In this study, increased soil compaction occurred throughout the soil profile with associated increases in $B D$ and $P R$ and reduction of $T P$, which has also been observed previously (Greacen \& Sands 1980, Sidle \& Drlica 1981, Gayoso \& Iroume 1991, Landsberg et al. 2003, Nugent et al. 2003, Ares et al. 2005, Eliasson \& Wasterlund 2007). However, relative to values from different soil depths in the control plots, changes in $B D$, $P R$ and $T P$ following machine traffic were often (but not always) highest in the upper 5 $\mathrm{cm}$ layer and lowest in the $20 \mathrm{~cm}$ layer of the soil profile. Compaction effects are generally most distinct in the upper soil layer, since the exerted pressure is maximal at the soil surface and declines with increasing depth as the total pressure is spread out over a growing area (Greacen \& Sands 1980, Ampoorter et al. 2010, Picchio et al. 2012). As soils are compacted and lose large pores after a few passes, compaction leads to higher soil strength in the upper soil layers, which prevents much further compaction of the surface layer with additional passes and shifts forces to deeper soil layers that are then increasingly compacted (Ampoorter et al. 2010, Picchio et al. 2012). Overall, damage to the soil (including deeper soil layers) was modest in this study, which might be bacause the intensity of machine traffic was generally at the low end compared to other studies (e.g., Zenner et al. 2007) and the very dry soil conditions on this site at the time of the forwarding operation were better able to resist to the mechanical soil compaction and rutting (e.g., Williamson \& Neilsen 2000, Bolding et al. 2009).

\section{Conclusion}

This study clearly demonstrates that changes in physical soil properties in response to farm tractor traffic are significantly affected by slope gradient and forwarding direction (i.e., uphill vs. downhill forwarding). Uphill forwarding, even on gentle slopes below $10 \%$ inclination, consistently caused more soil damage throughout the upper $20 \mathrm{~cm}$ of the soil profile than downhill forwarding on even steeper slopes. The pattern of the largest negative impact for uphill forwarding was the same for all three soil response variables, bulk density, resistance to penetration and total porosity, and at all traffic intensities along the skid trail. As a consequence, we recommend that skid trails have to be designed to avoid uphill forwarding by this farm tractor-2-wheel-trailer system. If possible, the application of this forwarding system should be limited to gentle slopes and alternative means of forwarding should be sought on steeper slopes. Given that impacts would have been even more severe had soils not been dry during the forwarding operation, logging operations should be restricted to periods when soil conditions are dry in order to minimize compaction and rutting. Future designs of skid trails should not only take into account the gradient of the slope of a skid trail, but also the direction of forwarding used by the chosen harvesting system.

\section{Acknowledgments}

The authors acknowledge the financial support by the University of Tehran for this research under grant number 28514/1/3.

\section{References}

Adams PW, Froehlich HA (1984). Compaction of forest soils. Extension Publication PNW 217, Pacific Northwest Research Station, USDA Forest Service, Portland, OR, USA, pp. 13.

Alban DH, Host GE, Elioff JD, Shadis D (1994). Soil and vegetation response to soil compaction and forest floor removal after aspen harvesting. Research Paper RP-NC-RP-315, North Central Forest Experiment Station, USDA Forest Service, St. Paul, MN, USA, pp. 8. [online] URL: http://www.treesearch.fs.fed.us/pubs/10798

Ampoorter E, de Schrijver A, Van Nevel L, Hermy M, Verheyen K (2012). Impact of mechanized harvesting on compaction of sandy and clayey forest soils: results of a meta-analysis. Annals of Forest Science 69: 533-542. - doi: 10.1007/s13595-012-0199-y

Ampoorter E, Van Nevel L, De Vos B, Hermy M, Verheyen K (2010). Assessing the effects of initial soil characteristics, machine mass and traffic intensity on forest soil compaction. Forest Ecology and Management 260: 1664-1676. - doi: 10.1016/j.foreco.2010.08.002

Ares A, Terry TA, Miller RE, Anderson HW, Flaming BL (2005). Ground-based forest harvesting effects on soil physical properties and douglas-fir growth. Soil Science Society of America Journal 69: 1822-1832. - doi: 10.2136/sssaj2004.0331

Bock MD, Van Rees KCJ (2002). Mechanical site preparation impacts on soil properties and vegetation communities in the Northwest Territories.
Canadian Journal of Forest Research 32: 13811392. - doi: 10.1139/x02-067

Bolding MC, Kellogg LD, Davis CT (2009). Soil compaction and visual disturbance following an integrated mechanical forest fuel reduction operation in Southwest Oregon. International Journal of Forest Engineering 20 (2): 47-56.

Brais S (2001). Persistence of soil compaction and effects on seedling growth in northwestern Quebec. Soil Science Society of America Journal 65: 1263-1271. - doi: 10.2136/sssaj2001.6541263x

Bustos O, Egan A (2011). A comparison of soil compaction associated with four ground-based harvesting systems. Northern Journal of Applied Forestry 28 (4): 194-198. [online] URL: http:// www.ingentaconnect.com/content/saf/njaf/2011/ 00000028/00000004/art00004

Conway S (1984). Logging practice, principles of timber harvesting systems. Miller Freeman Publications, San Francisco, USA, pp. 465.

Dykstra DP, Heinrich R (1996). FAO model code of forest harvesting practice. FAO, Rome, Italy, pp. 85 .

Eliasson L (2005). Effects of forwarder tire pressure on rut formation and soil compaction. Silva Fennica 39: 549-557. [online] URL: http://www. metsantutkimuslaitos.fi/silvafennica/full/sf39/sf3 94549.pdf

Eliasson L, Wasterlund I (2007). Effects of slash reinforcement of strip roads on rutting and soil compaction on a moist fine-grained soil. Forest Ecology and Management 252: 118-123. - doi: 10.1016/j.foreco.2007.06.037

Ezzati S, Najafi A, Rab MA, Zenner EK (2012). Recovery of soil bulk density, porosity and rutting from ground skidding over a 20 -year period after timber harvesting in Iran. Silva Fennica 46 (4): 521-538. [online] URL: http://www.silvafennica.fi/pdf/article908.pdf

Froehlich HA, McNabb DH (1984). Minimizing soil compaction in Pacific Northwest forests. In: "Forest soils and treatment impacts" (Stone EL ed). Proceedings of the "6th North American forest soils conference". Soil Science Society of America, Madison, WI, USA, pp. 159-192.

Gayoso J, Iroume A (1991). Compaction and soil disturbances from logging in Southern Chile. Annals of Forest Science 48: 63-71. - doi: 10.1051/forest:19910105

Gent JA, Morris LA (1986). Soil compaction from harvesting and site preparation in the upper Gulf Coastal Plain. Soil Science Society of America Journal 50: 443-446. - doi: 10.2136/sssaj1986.03 $615995005000020038 x$

Greacen EL, Sands R (1980). Compaction of forest soil, a review. Australian Journal of Soil Research 18: 163-189. - doi: 10.1071/SR9800 163 Greulich FR, Hanley DP, McNeel JF, Baumgartner D (1999). A primer for timber harvesting. EB1316, WSU Cooperative Extension, Pullman, Washington, USA, pp. 33.

Horn R, Vossbrink J, Peth S, Becker S (2007). Impact of modern forest vehicles on soil physical properties. Forest Ecology and Management 248: 56-63. - doi: 10.1016/j.foreco.2007.02.037

Ilstedta U, Malmerb A, Nordgrenb A, Liauc P 
(2004). Soil rehabilitation following tractor logging: early results on amendments and tilling in a second rotation Acacia mangium plantation in Sabah, Malaysia. Forest Ecology and Management 194: 215-222. - doi: 10.1016/j.foreco.2004 02.032

Jamshidi R, Jaeger D, Raafatnia N, Tabari M (2008). Influence of two ground-based skidding systems on soil compaction under different slope and gradient conditions. International Journal of Forest Engineering 19: 9-16. [online] URL: http://www.tandfonline.com/doi/abs/10.1080/14 942119.2008.10702554

Jourgholami M (2012). Small-scale timber harvesting; mule logging in Hyrcanian Forest. Smallscale Forestry 11 (2): 255-262. - doi: 10.1007/ s11842-011-9174-y

Krag R, Higgingbotham K, Rothwell R (1986). Logging and soil disturbance in southeast British Columbia. Canadian Journal of Forest Research 16: 1345-1354. - doi: 10.1139/x86-238

Landsberg JD, Miller RE, Anderson HW, Tepp JS (2003). Bulk density and soil resistance to penetration as affected by commercial thinning in northeastern Washington. Research Paper PNWRP-551, Pacific Northwest Research Station, USDA Forest Service, Portland, OR, USA, pp. 35. [online] URL: http://citeseerx.ist.psu.edu/ viewdoc/download?doi=10.1.1.124.120\&rep= rep1\&type $=$ pdf

McNabb DH, Startsev AD, Nguyen H (2001). Soil wetness and traffic level effects on bulk density and air-filled porosity of compacted boreal forest soils. Soil Science Society of America Journal 65: 1238-1247. - doi: 10.2136/sssaj2001.65412 $38 \mathrm{x}$

Miller D, Anderson H (2002). Soil compaction: concerns, claims, and evidence. In: Proceedings of the Meeting "Small Diameter Timber: Resource Management, Manufacturing, and Markets". Spokane (Washington, USA) 25-27 Feb 2002. Washington State University Cooperative Extension, Friday Harbor, WA, USA, pp. 97 106.

Mousavi R (2009). Comparison of productivity, cost and environmental impacts of two harvesting methods in northern Iran: short-log vs. long-log. PhD thesis, Faculty of Forest Sciences, University of Joensuu, Finland, pp. 93.

Murphy G, Firth JG, Skinner MF (2004). Long- term impacts of forest harvesting related soil disturbance on log product yields and economic potential in a New Zealand forest. Silva Fennica 38 (3): 279-289. [online] URL: http://www.metla.fi/ silvafennica/full/sf38/sf383279.pdf

Nugent C, Kanali C, Owende PMO, Nieuwenhuis M, Ward S (2003). Characteristic site disturbance due to harvesting and extraction machinery traffic on sensitive forest sites with peat soils. Forest Ecology and Management 180: 8598. - doi: 10.1016/S0378-1127(02)00628-X

Picchio R, Neri F, Petrini E, Verani S, Marchi E, Certini G (2012). Machinery-induced soil compaction in thinning two pine stands in central Italy. Forest Ecology and Management 285: 3843. - doi: 10.1016/j.foreco.2012.08.008

Rab MA (1996). Soil physical and hydrological properties following logging and slash burning in the Eucalyptus regnans forest of southeastern Australia. Forest Ecology and Management 84: 159-176. - doi: 10.1016/0378-1127(96)03740-1

Rodriguez EO (1986). Wood extraction with oxen and agricultural tractors. FAO Forestry Paper No. 49, Rome, Italy, pp. 120. [online] URL: http://books.google.com/books?id=MbFrIMio_H $\mathrm{AC}$

Rohand K, Kalb AA, Herbauts J, Verbrugge JC (2004). Changes in some mechanical properties of a loamy soil under the influence of mechanized forest exploitation in a beech forest of central Belgium. Journal of Terramechanics 40: 235-253. - doi: 10.1016/j.jterra.2003.12.004

Russell F, Mortimer D (2005). A review of smallscale harvesting systems in use worldwide and their potential application in Irish forestry. COFORD, Dublin, Ireland, pp. 48. [online] URL: http://www.betterenergyhomes.ie/Renewables/Bi oenergy/Review_of_small_scale_harvesting_systems.pdf

Savelli S, Cavalli R, Baldini S, Picchio R (2010). Small scale mechanization of thinning in artificial coniferous plantation. Croatian Journal of Forest Engineering 31 (1): 11-21. [online] URL: http://hrcak.srce.hr/56924?lang=en

Shaffer RM (1992). Farm tractor logging for woodlot owners. College of Natural Resources, Virginia Polytechnic Institute and State University, Blacksburg, VA, USA, pp. 5.

Sidle RC, Drlica DM (1981). Soil compaction from logging with a low-ground pressure skidder in the Oregon Coast Ranges. Soil Science Society of America Journal 45: 1219-1224. - doi: 10.2136/sssaj1981.03615995004500060042x Spinelli R, Magagnotti N (2012). Wood extraction with farm tractor and sulky: estimating productivity, cost and energy consumption. Small-scale Forestry 11 (1): 73-85. - doi: 10.1007/s11 842011-9169-8

Susnjar M, Horvat D, Seselj J (2006). Soil compaction in timber skidding in winter conditions. Croatian Journal of Forest Engineering 27: 3-15. [online] URL: http://hrcak.srce.hr/index.php? show $=$ clanak\&id clanak jezik $=6550 \&$ lang $=$ en Updegraff K, Blinn CR (2000). Applications of small-scale forest harvesting equipment in the United States and Canada. Staff Paper Series no. 143, College of Natural Resources and Minnesota Agricultural Experiment Station, University of Minnesota, St. Paul, MN, USA, pp. 51. [online] URL: http://conservancy.umn.edu/bitstream/11299/37096/1/Staffpaper143.pdf

Wang J, LeDoux CB, Edwards P (2007). Changes in soil bulk density resulting from construction and conventional cable skidding using preplanned skid trails. Northern Journal of Applied Forestry 24: 5-8.

Williamson JR, Neilsen WA (2000). The influence of forest site on rate and extent of soil compaction and profile disturbance of skid trails during ground-based harvesting. Canadian Journal of Forest Research 30: 1196-1205. - doi: 10.113 9/x00-041

Wronski EB, Murphy G (1994). Responses of forest crops to soil compaction. In: "Soil Compaction in Crop Production" (Soane BD, van Ouwerkerk C eds). Elsevier, Amsterdam, The Netherlands, pp. 317-342.

Zenner EK, Berger AL (2008). Influence of skidder traffic and canopy removal intensities on the ground flora in a clearcut-reserves northern hardwood stand in Minnesota, USA. Forest Ecology and Management 256: 1785-1794. - doi: 10.10 16/j.foreco.2008.05.030

Zenner EK, Fauskee JT, Berger AL, Puettmann KJ (2007). Impacts of skidding traffic intensity on soil disturbance, soil recovery, and aspen regeneration in north central Minnesota. Northern Journal of Applied Forestry 24: 177-183. [online] URL: http://www.cof.orst.edu/cof/fs/kpuett mann/NJAF\%2024(3)\%202007.pdf 